\title{
Effect of Enzyme Preparation with Activity Directed Towards Degradation of Non Starch Polysaccharides on Yellow Lupine Seed Based Diet for Young Broilers
}

\author{
Bogusław I Olkowski ${ }^{1}$, Izabela Janiuk ${ }^{2}$, Antoni Jakubczak ${ }^{3}$ \\ ${ }^{1}$ Department of Animal Nutrition, ${ }^{2}$ Department of Vertebrates Morphology, Faculty of Life Sciences, \\ University of Natural Sciences and Humanities, Siedlce, Poland \\ ${ }^{3}$ Food Technology Institute, The State College of Computer Science and Business Administration, \\ Łomża, Poland
}

Received May 21, 2009

Accepted May 13, 2010

\begin{abstract}
This work examined the impact of enzyme preparation with specific activity towards non starch polysaccharides on performance, morphological characteristics of gastrointestinal tract organs, microscopic evaluation of jejunal mucosa, and microbial status of ileum, caeca, and excreta in broilers fed a diet containing a high content of lupine meal. One-day-old chickens (Ross 308, mixed sex) were randomly divided into control and experimental groups. Each group consisted of 36 birds, with 6 replications, and with 6 chickens per replication. The control group was fed the basal diet (consisting of maize and $40 \%$ of lupine), while the experimental treatment group was fed the basal diet supplemented with $0.06 \%$ commercial enzyme (Ronozyme VP). Chickens were fed diets in mash form for 4 weeks. Enzyme preparation significantly $(P<0.05)$ improved feed consumption and chicken growth, and slightly improved total tract digestibility of dietary ingredients and energy. Enzyme preparation significantly reduced $(P<0.05)$ the size of gastrointestinal tract organs and had an impact on jejunal mucous membrane of chickens evidenced by elongation of villi and deepening of crypts. No significant effects of dietary enzyme on counts of the analysed bacteria in the jejunal digesta were observed, but enzyme preparation significantly $(P<0.05)$ reduced the number of Enterobacteriaceae in caeca and excreta, and coliforms in excreta only $(P<0.01)$. Appropriate combination of enzyme preparations with activity towards degrading carbohydrates may offer a potential to reduce the deleterious impact of lupine in broilers.
\end{abstract}

Chicken growth, Lupinus luteus, carbohydrates, feed enzymes, gastrointestinal tract

Soybean meal (SBM) is the most common protein supplement widely used in poultry feed, but in many countries including a majority of EU, SBM is an imported commodity. An alternative to SBM in countries with limited soy cultivation are other high protein grain legumes. For instance, lupine seed meal (LM) offers protein with acceptable nutritional quality (Petterson 2000). A desirable quality of LM means that it does not contain significant amounts of typical anti-nutritional factors (phytates, lectins, tannins, trypsin inhibitor) found in the seeds of other leguminous plants. Alkaloids, the main drawback of lupine in the past, are no problem nowadays as the modern varieties of cultivated lupines (called sweet) contain only trace quantities of these toxins. At present, the most important factor limiting the use of lupines in poultry are non-starch polysaccharides (NSP), which may constitute up to 40\% (Petterson 2000; Kluge et al. 2002).

In poultry, lupine NSP are poorly digestible. A high content of NSPs results in elevated ileal content viscosity and excreta moisture, which have a negative impact on feed intake and efficiency (Annison et al. 1996; Naveed et al. 1999; Kocher et al. 2000; Steenfeldt et al. 2003). Rubio et al. (1998) found that lupines may also affect the microbiological status in broiler chicken intestines. Decreased performance of young broilers fed a diet with high content of LM was observed by several authors (Brenes et al. 1993; Olkowski et al. 2001, 2005; Roth-Maier and Paulics 2003; Steenfeldt et al. 2003; Diaz et al. 2006). 
Among cultivated lupine species, yellow lupines (Lupinus luteus) have the highest protein content of up to $460 \mathrm{~g} / \mathrm{kg}$, with an amino acid profile better than other lupines (Sujak et al. 2006) and the lowest content of NSP (Kluge et al. 2002). Because of the detrimental effects of NSP, lupine seeds appear to be underutilised as protein source for poultry. The negative effects of NSP in broilers can be reduced by adding dietary enzymes degrading these compounds (Choct 2006).

The benefits of enzyme preparations have been studied in lupine based diets; however, most experiments were conducted using Lupinus angustifolius and Lupinus albus (Annison et al. 1996; Naveed et al. 1998, 1999; Brenes et al. 2002; Steenfeldt et al. 2003; Mieczkowska et al. 2004). Given the fact that Lupinus luteus appears to have the most desirable qualities as a potential primary protein source for broiler chicken diets (Petters on 2000), there is insufficiency of data on the effects of enzyme preparations on NSP in diets based on Lupinus luteus.

Our preliminary studies showed that supplementation of LM based diets for young broilers with commercial multienzyme preparation (Energex) has the potential to reduce the anti-nutritional effects of NSPs in Lupinus luteus seed. The aim of the present study was to test the effects of the next generation of Energex enzyme preparation brand Ronozyme VP added to diets containing seeds of Lupinus luteus as the primary source of protein on nutritional efficiency and gastrointestinal indicators in broilers.

\begin{abstract}
Material and Methods
Diets

Meal prepared from Lupinus luteus seeds was used as the primary source of protein. The LM was first analyzed for chemical composition including amino acids and anti-nutritional factors, and added at a concentration of $400 \mathrm{~g} / \mathrm{kg}$ to corn meal based diet for broilers. Other components of the diet included soybean oil, corn gluten, synthetic amino acids, limestone, dicalcium phosphate, salt and premix (BASF-Poland $0.5 \%$ contained in $\mathrm{g} / \mathrm{kg}$ : Ca 187.3; Fe 16.0; Zn 14.0; Mn 16.0; Cu 1.8; I 0.25; Se 0.055; Co 0.06; Vit.E 16.0; Vit. K 0.6; Vit. B 0.5; Vit. B 1.75; Vit. B 1.0; Vit. B 0.0048; Biotin 0.04; Folic acid 0.3; Nicotinic acid 10.0; Calcium pantothenate 5.43; Choline 100.0 or (IU/kg ) : Vit. A 3.000.000; Vit. D 500.000). The basal diet was prepared to provide metabolizable energy $\left(\mathrm{AME}_{\mathrm{n}}\right)$, crude protein, limiting essential amino acids, $\mathrm{Ca}$ and $\mathrm{P}$, and mineral-vitamin with starter premix according to nutritional requirements of broilers. Calculated nutritional value of the basal diet (per kg) comprised: 12.25 MJ AMEn, $210 \mathrm{~g}$ crude protein, $12 \mathrm{~g}$ lysine, $9 \mathrm{~g}$ methionine + cystine, $6.9 \mathrm{~g}$ threonine, $2 \mathrm{~g}$ tryptophane, $12 \mathrm{~g}$ calcium, $4.7 \mathrm{~g}$ available phosphorus. The basal diet contained $130 \mathrm{~g}$ non-starch polysaccharides.

The experimental diet arrangement included the basal diet supplemented with $0.6 \mathrm{~g} / \mathrm{kg}$ of enzyme preparation (EP) (Ronozyme VP (CT), Hoffmann-La Roche Ltd, Basel, Switzerland contained: endo-1,3(4)- $\beta$-glucanase with activity $50 \mathrm{FBG} / \mathrm{g}$, pentozanase with activity $7000 \mathrm{PSU} / \mathrm{g}$, haemicellulase and pectinase activity).
\end{abstract}

Animals and measurements

One day-old commercial broiler chickens (Ross 308, mixed sex) were randomly divided into a control group (fed basal diet) and the experimental group (fed basal diet + EP). Each group included 36 chickens ( 6 replicates with 6 chickens per replicate). The chickens were housed in metal cages located in climatically controlled rooms. The water and diets (mash) were offered ad libitum from day 1 of age. At week 4 , chickens were subjected to a short digestibility trial. On day 20, all birds were without diet for $18 \mathrm{~h}$, and then re-fed their diet for $72 \mathrm{~h}$. Following this, chickens were again without diet for $18 \mathrm{~h}$. During the digestibility study, excreta were collected twice a day, with particular attention paid to excluding the contaminants (downs, feathers and scales). The collected excreta were dried immediately at $60{ }^{\circ} \mathrm{C}$ for $72 \mathrm{~h}$. Following drying, the samples were chilled, ground, and stored until further analysis.

After the digestibility study, chickens were given the same diets ad libitum until the end of the experiment. At day 28, all chickens were weighed and feed consumption measured. For morphometric and microbiological measurements, two male chickens per each replication (twelve per group) were euthanized; the entire gastrointestinal tract (GIT) was excised and subjected to post mortem examination. Immediately the contents of the jejunum, caeca and fresh faeces were aseptically collected and placed in cooled containers. Samples of digesta or excreta from 2 birds were pooled in replication, stored at $-30{ }^{\circ} \mathrm{C}$ and subjected to further analysis. Internal organs were subjected to morphometric measurements including weight (liver, pancreas and gizzard), and length (small intestine and caeca). Tissue sections $(\sim 3 \mathrm{~cm}$ long) from middle jejunum were cut, gently flushed with cold saline and immediately fixed in $4 \%$ neutral buffered formalin. Following fixation, the samples were embedded in paraffin, sectioned $(\sim 5 \mu \mathrm{m})$, and stained with haematoxylin and eosin for histological evaluation. The experiment was conducted in agreement with the Polish regulations regarding the protection of experimental animals. 
Analyses and statistics

Lupine seeds were analyzed for basic nutrients, amino acids, phytates, total alkaloids, condensed tannins, non starch polysaccharides (NSP), lectins and gross energy. Basic nutrients and energy were determined using the procedures according to the Association of Official Analytical Chemists (AOAC 1990). Gross energy was measured using oxygen bomb calorimeter KL-6. Amino acids content was determined using Amino Acid Analyzer system (Beckman Gold 126AA) as described by Llames and Fontaine (1994) with the exception of tryptophan, which was determined according to the Polish Standard (PN-77/R-64820). Total alkaloids were analyzed according to the method described by Skolik and Wiewiorowski (1959). Phytates were determined as phytic acid using HPLC method (Newkirk and Classen 1998); condensed tannins as described by Buttler et al. (1982). NSP were analyzed using GLC method as described by Englyst (1989). Lectins (galactose binding) were measured by affinity chromatography according to Maenz et al. (1999). Samples of the diet and excreta were subjected to measurements of dry matter, crude protein, crude ash, crude fat, and gross energy using the same methods as used for analysis of lupine seeds (see above). Excreta were additionally analyzed for uric acid nitrogen as described by Ekman et al. (1949). The coefficients of apparent total tract digestibility of organic matter, protein, fat and energy were calculated.

Samples of the intestinal content or excreta were weighed, diluted in $9 \mathrm{ml}$ of sterile saline solution, mixed thoroughly, and plated on a specific bacterial culture media for total aerobic bacteria (Nutrient agar), Escherichia coli (Chromocult Coliform agar), Enterobacteriaceae (VRDL agar), Lactobacillaceae (MRS agar) and Coliforms (MacConkey agar). All media were incubated for $48 \mathrm{~h}$ at $37^{\circ} \mathrm{C}$ under aerobic conditions, except MRS agar which was incubated in anaerobic conditions. Bacteria colony forming units (CFU) were enumerated, and expressed in a $\log _{10}$ scale per $1 \mathrm{~g}$ of sample.

The histological slides were examined on computer-aided light microscopic image analyzer (Olympus B41 microscope, using analySIS - Cell Soft Imaging System software). Measurements included jejunal villus height (from the tip of villus to the crypt opening) and crypt depth (from the base of the crypt to the level of crypt opening). For each chicken, values used for analysis were calculated as means from 10 adjacent, vertically oriented villus-crypt units per section.

Table 1. Energy (MJ/kg), basic nutrient, and amino acid content $(\mathrm{g} / \mathrm{kg})$ in yellow lupine seeds (as fed basis)

\begin{tabular}{|l|c|}
\hline Ingredient & Content \\
\hline Gross energy $(\mathrm{GE})$ & 17.2 \\
\hline Metabolizable energy AME & 8.25 \\
\hline Dry matter & 869.1 \\
\hline Crude ash & 36.9 \\
\hline Crude protein & 398.4 \\
\hline Crude fat & 39.0 \\
\hline Crude fibre & 159.7 \\
\hline N-free extractives & 235.1 \\
\hline Cystine & 8.6 \\
\hline Aspartic acid & 38.4 \\
\hline Methionine & 3.0 \\
\hline Threonine & 11.3 \\
\hline Serine & 18.8 \\
\hline Glutamic acid & 88.8 \\
\hline Proline & 15.7 \\
\hline Glycine & 14.5 \\
\hline Alanine & 11.6 \\
\hline Valine & 13.2 \\
\hline Isoleucine & 13.7 \\
\hline Leucine & 28.2 \\
\hline Phenylalanine & 14.0 \\
\hline Histidine & 10.5 \\
\hline Lysine & 18.1 \\
\hline Arginine & 41.8 \\
\hline Tyrosine & 9.1 \\
\hline Tryptophan & 2.7 \\
\hline & \\
\hline
\end{tabular}

The results were analyzed by one-way factor analysis of variance and the significance of differences between means was determined by $t$-test using microcomputer package NCSS.

\section{Results}

The chemical composition of basic ingredients in seeds was characteristic for seeds of this lupine species (Table 1). Although gross energy (GE) level was relatively high $(17.2 \mathrm{MJ} / \mathrm{kg})$, the apparent metabolizable energy $\left(\mathrm{AME}_{\mathrm{n}}\right)$ calculated according to the WPSA (1998) formula showed only $50 \%$ of GE. The amount of lupine protein amino acid dominated by glutamic acid was amounted to more than $\sim 1 / 5$ of crude protein. A high content of arginine $(\sim 42 \mathrm{~g} / \mathrm{kg}$ ) was noticed. Despite a low content of methionine $(3 \mathrm{~g} / \mathrm{kg})$, the total amount of sulphurcontaining amino acids was relatively high $(\sim 12 \mathrm{~g} /$ $\mathrm{kg}$ ). Lysine constituted $4.5 \mathrm{~g} / 100 \mathrm{~g}$ of lupine protein. The relative (\% lysine) ratio of primary amino acids was as follows: Lys (100), Met (16.6), Trp (14.9) and, $\operatorname{Thr}(62.4)$.

The lupine seeds contained relatively low amounts of typical anti-nutritional factors (Table 2 ). Of these factors, phytates were in the highest concentration (approximately $15 \mathrm{~g} / \mathrm{kg}$ ), whereas total alkaloids or phenolics were considerably lower amount (400-600 mg/kg). The LM contained $1.2 \mathrm{~g}$ of lectin (galactose binding) per $1 \mathrm{~kg}$. There were no detectable concentrations of condensed tannins. 
Table 2. The content of NSP components, and anti-nutritional factors in yellow lupine seeds (dry matter based)

\begin{tabular}{|c|c|c|}
\hline Ingredient & Unit & Content \\
\hline Glucose & $\mathrm{g}$ & 87.0 \\
\hline Galactose & $\mathrm{g}$ & 50.8 \\
\hline Arabinose & $\mathrm{g}$ & 36.8 \\
\hline Xylose & $\mathrm{g}$ & 29.6 \\
\hline Uronic acids & $\mathrm{g}$ & 36.4 \\
\hline Mannose & $\mathrm{g}$ & 3.4 \\
\hline Rhamnose & $\mathrm{g}$ & 1.3 \\
\hline Fucose & $\mathrm{g}$ & 0.9 \\
\hline Soluble NSP & $\mathrm{g}$ & 70.0 \\
\hline Insoluble NSP & $\mathrm{g}$ & 175.6 \\
\hline Total NSP & $\mathrm{g}$ & 245.6 \\
\hline Total phytates & $\mathrm{g}$ & 15.3 \\
\hline Total alkaloids & $\mathrm{mg}$ & 600 \\
\hline Lectins $^{1}$ & $\mathrm{~g}$ & 1.2 \\
\hline Total phenolics & $\mathrm{mg}$ & 440.2 \\
\hline Condensed tannins & $\mathrm{mg}$ & nd \\
\hline
\end{tabular}

$\mathrm{NSP}=$ non starch polysaccharides; ${ }^{1}$ with affinity to galactose only; nd = not detected

Table 3. Effects of enzyme preparation on performance and morphometric indicators of chicken fed yellow lupine based diet

\begin{tabular}{|c|c|c|c|}
\hline \multirow{2}{*}{ Indicator (unit) } & \multicolumn{3}{|c|}{ Diet/group } \\
\hline & Basal & Basal + EP & SE \\
\hline Body weight gain (g/day) & 35.0 & 38.6 & $0.8^{*}$ \\
\hline Feed intake (g/day) & 61.7 & 65.2 & $1.2^{*}$ \\
\hline Feed conversion ratio $(\mathrm{g} / \mathrm{g})$ & 1.76 & 1.69 & 0.05 \\
\hline Mortality (number) & 1 & 2 & - \\
\hline Gizzard weight $^{1}(\mathrm{~g})$ & 3.78 & 3.21 & $0.15^{*}$ \\
\hline Liver weight $^{1}(\mathrm{~g})$ & 3.59 & 3.27 & $0.09^{*}$ \\
\hline Pancreas weight $^{1}(\mathrm{~g})$ & 0.39 & 0.31 & $0.02^{*}$ \\
\hline Duodenum length $^{1}(\mathrm{~cm})$ & 4.64 & 3.99 & $0.16^{*}$ \\
\hline Jejunum length $^{1}(\mathrm{~cm})$ & 9.86 & 8.64 & $0.32^{*}$ \\
\hline Illeum length $^{1}(\mathrm{~cm})$ & 8.84 & 8.14 & $0.31^{*}$ \\
\hline Total small intestine length ${ }^{1}(\mathrm{~cm})$ & 23.34 & 20.77 & $0.77^{*}$ \\
\hline Caeca length $^{1}(\mathrm{~cm})$ & 2.24 & 1.97 & $0.04^{*}$ \\
\hline Jejunal crypt depth $(\mu \mathrm{m})$ & 206.5 & 280.4 & $8.0^{* * *}$ \\
\hline Jejunal villus hight $(\mu \mathrm{m})$ & 957.1 & 1034.0 & $18.0^{* *}$ \\
\hline
\end{tabular}

${ }^{1}$ Presented values are normalized for body weight (g or cm per $100 \mathrm{~g}$ body weight).

$\mathrm{SE}=$ Standard error of the mean; ${ }^{*} P<0.05 ;{ }^{* *} P<0.01$
Total NSP was $\sim 1 / 4$ of lupine seeds, and $70 \%$ of it was water insoluble. Among monosaccharides glucose and galactose were dominant sugars, followed by uronic acids, arabinose and xylose. Pentose sugars (xylose + arabinose) accounted for $27 \%$ of the NSP content. The remaining monosaccharide was mannose, rhamnose and fucose.

Enzyme preparation (EP) significantly improved $(P<0.05)$ chickens' growth by $\sim 10 \%$, improved the feed intake by $\sim 5 \%$, and decreased the size $(P<0.05)$ of digestive tract elements in relation to body mass (Table 3). Microscopic evaluation revealed the influence of EP on jejunal microstructure. Significant $(P<0.01)$ increases in villi height and crypts depth were recorded.

Enzyme preparations slightly improved $(P<0.05)$ digestibility of organic matter, dietary energy and fat, but differences in protein digestibility were not significant (Table 4).

The number $\left(\log _{10} \mathrm{CFU}\right)$ of analysed bacteria groups in the intestinal content ranged from 2.6 to 7.3, and in excreta from 4.8 to 9.3 (Table 5).

Counts of total aerobic bacteria, Enterobacteriaceae and coliforms in jejunal content were lower than those in caeca $(P<0.01)$ or excreta $(P<$ $0.001)$. Population of $E$. coli in excreta and Lactobacillaceae in caeca were the highest. Enzyme preparations did not cause any significant quantitative changes in bacterial status in jejunum, but resulted in a decreased $(P<0.05)$ number of Enterobacteriaceae in caeca. Enzyme preparations reduced the number of Enterobacteriaceae and coliform population in excreta (both $P<0.01$ ).

\section{Discussion}

The content of basic ingredients and amino acids was typical for varieties of yellow lupine seeds (Petterson 2000; Sujak et al. 2006; Strakova et al. 2006). Lupine meal contains a high content of arginine, which is often deficient in the feeding mixtures (Suchy et al. 2006). The content of essential amino acids in lupine, such as methionine and to some extent lysine, tryptophan, and threonine, does not meet the ideal protein requirements of broilers. Therefore, there is a need for supplementation of these amino acids to chicken diets based on a high content of lupine. 
Table 4. Effect of enzyme preparation on total tract apparent digestibility in chickens fed yellow lupine based diet

\begin{tabular}{|l|c|c|c|}
\hline \multirow{2}{*}{ Item } & \multicolumn{3}{|c|}{ Diet/group } \\
\cline { 2 - 4 } & Basal & Basal + EP & SE \\
\hline Organic matter & 0.679 & 0.707 & $0.010^{*}$ \\
\hline Crude protein & 0.568 & 0.592 & 0.012 \\
\hline Crude fat & 0.815 & 0.837 & $0.008^{*}$ \\
\hline Energy & 0.703 & 0.735 & $0.009^{*}$ \\
\hline
\end{tabular}

$\mathrm{SE}=$ Standard error of the mean; ${ }^{*} P<0.05 ;{ }^{* *} P<0.01$
Low metabolizable energy $\left(\mathrm{AME}_{\mathrm{n}}\right)$ of $\mathrm{LM}$ in the present study confirms the results reported by other authors (Alloui et al. 1994; Petterson 2000). A very low content of $\mathrm{AME}_{\mathrm{n}}$ in lupine based diets is the result of high presence of NSP in lupine seeds (Kocher et al. 2000). It has been calculated that for every percent of lupine NSP in the diet for broilers there is a decrease of $0.288 \mathrm{MJ}$ in metabolizable energy (Sipsas and Glencross 2005). Therefore, it is essential that diets for broilers based on a high lupine content are properly balanced for $\mathrm{AME}_{\mathrm{n}}$.

Table 5. Effect of EP on bacterial counts $\left(\mathrm{CFU} / \mathrm{g}, \log _{10}\right)$ in intestinal digesta and excreta of chickens fed yellow lupine based diet

\begin{tabular}{|c|c|c|c|c|}
\hline \multicolumn{2}{|l|}{ Bacteria group/location } & \multicolumn{3}{|c|}{ Diet/group } \\
\hline & & Basal & Basal + EP & $\mathrm{SE}$ \\
\hline \multirow{3}{*}{ Total aerobic bacteria } & Jejunum & 6.16 & 4.94 & 0.77 \\
\hline & Caeca & 7.65 & 6.63 & 0.83 \\
\hline & Excreta & 8.69 & 8.09 & 0.44 \\
\hline \multirow{3}{*}{ Escherichia coli } & Jejunum & 3.63 & 4.08 & 0.37 \\
\hline & Caeca & 4.06 & 4.00 & 0.35 \\
\hline & Excreta & 5.34 & 4.84 & 0.55 \\
\hline \multirow{3}{*}{ Enterobacteriaceae } & Jejunum & 4.40 & 4.23 & 0.71 \\
\hline & Caeca & 7.30 & 6.01 & $0.37^{*}$ \\
\hline & Excreta & 9.26 & 5.88 & $0.33^{* *}$ \\
\hline \multirow{3}{*}{ Coliforms } & Jejunum & 2.56 & 2.59 & 0.09 \\
\hline & Caeca & 6.79 & 7.14 & 0.27 \\
\hline & Excreta & 8.48 & 6.83 & $0.30^{* *}$ \\
\hline \multirow{3}{*}{ Lactobacillaceae } & Jejunum & 4.04 & 4.90 & 0.97 \\
\hline & Caeca & 6.65 & 6.34 & 0.57 \\
\hline & Excreta & 5.31 & 4.85 & 0.65 \\
\hline
\end{tabular}

$\mathrm{SE}=$ Standard error of the mean; ${ }^{*} P<0.05 ;{ }^{* *} P<0.01$

The content of typical anti-nutritional factors observed in the present study was generally in the range of values reported by other researchers. Total alkaloids were within the limits for Polish sweet varieties of yellow lupine (Sujak et al. 2006) and correspond with the data of Petters on (2000). The content of phytates was $\sim 15 \mathrm{~g} / \mathrm{kg}$ which is comparable with the contents found by other authors (Martinez-Villaluenga et al. 2006). Interestingly, Australian lupines (Petters on 2000) appear to contain $3 \times$ lower concentrations of phytates $(\sim 5 \mathrm{~g} / \mathrm{kg})$. Because the phytate content in yellow lupine may be as high as $\sim 4 \%$ (Birk 1994), it should be monitored. Galactose binding lectins were found in concentration of $1.2 \mathrm{~g} / \mathrm{kg}$. The lectin content assessed by the same method in soybean meal was 0.2 to $3.1 \mathrm{~g} / \mathrm{kg}$ and the lectins showed agglutinating activity (Maenz et al. 1999; Fasina et al. 2003). It is well established that plant lectins can be detrimental to animals (Vasconcelos and Oliveira 2004). According to Petterson (2000), in extracts from L. angustifolius or L. albus in standard tests, there is no lectin activity, and slight agglutinating activity can be induced if the red cells are specially treated, but this is not considered biologically significant. Lectinlike protein in lupine has slight haemaglutinating properties in vitro but it is toxic in vivo, 
exerting toxicity by interfering with protein synthesis in the liver in rats (Rahman 2000). Generally, 30-40\% of lupine seeds in chicken diet reduce nutritional effectiveness of the diet (Gilbert et al. 2000a; Roth-Maier and Paulics 2003, Steenfeld et al. 2003). The negative impact of lupines is mainly attributed to large quantities of NSP. In the present study, the total NSP content was $246 \mathrm{~g} / \mathrm{kg}$ which corresponds with the results of Kluge et al. (2002).

Dietary addition of enzyme preparation (Ronozyme VP) significantly improved nutritional effectiveness of the diet. The observed tendency to improve the growth and digestibility as a result of enzyme used is in agreement with the results of other trials with different enzyme preparations used in diets for broiler chickens (Brenes et al. 1993, 2002; Alloui et al. 1994; Annison et al. 1996; Naveed et al. 1999; Ali et al. 2005; Orda et al. 2006). Significant improvement of NSP digestion from lupine diet enriched with NSP specific enzymes was observed by Kocher et al. (2000). Also, addition of enzymes to a lupine diet can increase energy metabolizability (Brenes et al. 1993; Marquardt et al. 1996) and the utilization of protein and amino acids (Ferraz de Oliveira and Acamovic 1999; Wiryawan and Dingle 1999).

It is well established that a high content of lupine in a diet induces gastrointestinal tract hypertrophy in chickens (Brenes et al. 2002; Olkowski et al. 2005). Enzyme preparation used in the present study lead to partial reduction of GIT morphometric variables, which is consistent with the results of researches applying various NSP enzymes to diets based on L. albus and L. angustifolius (Brenes et al. 1993; Brenes et al. 2002; Rubio et al. 2003). However, it appears that nutritional effectiveness of NSP enzyme preparations may depend not only on type of enzyme, but also on species of lupine (Alloui et al. 1994; Annis on et al. 1996; Brenes et al. 1993, 2002). The impact of enzymes can be minor or even negative (Anninson et al. 1996; Naveed et al. 1998; Kocher et al. 2000; Rubio et al. 2003; Steenfeldt et al. 2003; Froidmont et al. 2004;).

According to Iji et al. (2001), the presence of NSP in a diet resulteds in enlargement of intestinal villi in chickens, but Jamroz (2005) suggests that the effect of NSP is based on a reduction of intestinal villi and deepening of crypts. In our study, EP had a significant $(P<0.01)$ impact on intestinal mucosa morphology evidenced by slight elongation of villi and deepening of crypts. In contrast, Gilbert et al. (2000a) claimed that although white lupine enlarged intestinal villi in chickens, the addition of enzymes (xylanase and cellulase) reduced their size. Our findings are in agreement with the results of researchers (Mathlouthi et al. 2002; Gracia et al. 2003; Mathivanan et al. 2006), who applied enzymes targeting NSP to various diets for chickens, but without lupine.

Composition of the diet can affect the microbiological status of intestinal content in chickens. Rubio et al. (1998) found that a diet with high concentration of lupine increased the number of Lactobacillus in caeca, but not of E. coli. Types of bacteria as well as their activity in chickens' intestines may depend on enzyme additives (Rosin et al. 2007). We recorded decrease $(P<0.01)$ of Enterobacteriaceae in caeca and Enterobacteriaceae and coliform in excreta. The presence of NSP in chicken digesta may lead to increased concentration of volatile fatty acids, which can inhibit microbial proliferation in the small intestine (Jozefiak et al. 2004). Orda et al. (2006) found a significant reduction of $E$. coli population and an increase in Lactobacillus in the large intestine content of chickens as a result of adding the same type of EP (Ronozyme VP) to a diet containing $20 \%$ of L. luteus. The gene-based analysis of microbes suggests increased proliferation of Enterobacteriaceae in caeca of chicken fed a diet with L. albus (Apajalahti and Bedford 2000). Decreased number of growth-impeding bacteria were recorded in caeca with addition of xylanase or cellulase to the same diet for chicken (Gilbert et al. 2000b). The reduction number of Enterobacteriaceae and coliform bacteria in excreta observed in our study may indicate an improvement in litter hygiene. The use of appropriate enzymes may allow broader 
application of yellow lupine seeds as the primary source of protein in diets for young broiler chickens.

\section{References}

Ali A, Williams IH, Martin GB, Sipsas S 2005: Hydrolysis of lupin pectin by pectinases for broilers. Proc Aust Poult Sci Symp 17: 219-222

Alloui O, Smulikowska S, Chibowska M, Pastuszewska B 1994: The nutritive value of lupin seeds (L. luteus, L. angustifolius and L. albus) for broiler chickens as affected by variety and enzyme supplementation. J Anim Feed Sci 3: 215-227

Annison G, Hughes RJ, Choct M 1996: Effects of enzyme supplementation on the nutritive value of dehulled lupins. Br Poult Sci 37: 157-172

AOAC 1990: Official methods of analysis of the ssociation of official analytical chemists association of official analytical chemists, $15^{\text {th }}$ ed., Arlington, VA

Apajalahti J, Bedford M 2000: Impact of dietary and environmental factors on microbial ommunities of the avian GI tract. Proceedings of XXI World's Poultry Congress (CD), Montreal, Canada

Birk Y 1994: Antinutritive factors (ANFs) in lupins and in other legume seeds. Advances in Lupin Research. Proceedings of 7th International Lupin Conference, Evora, Portugal ISA Press, pp. 424-429

Brenes A, Marquardt RR, Guenter W, Rotter BA 1993: Effect of enzyme supplementation on the nutritional value of raw, autoclaved, and dehulled lupins (Lupinus albus) in chicken diets. Poult Sci 72: 2281-2293

Brenes A, Marquardt RR, Guenter W, Viveros A 2002: Effect of enzyme addition on the performance and gastrointestinal size of chicks fed whole, dehulled lupins and lupin hulls diets. Poult Sci 81: 670-678

Buttler LG, Price ML, Brotheorton JE 1982: Vanillin assay for proathocyjanidins (condensed tannins): modification of the solvent for estimation of degree of polymerization. J Agric Food Chem 30: 1087-1089

Choct M 2006: Enzymes for the feed industry: past, present and future. World Poult Sci J 62: 5-15

Diaz D, Morlacchini M, Masoero F, Moschini M, Fusconi G, Piva G 2006: Pea seeds (Pisum sativum), faba beans (Vicia faba var. minor) and lupin seeds (Lupinus albus var. multitalia) as protein sources in broiler diets: effect of extrusion on growth performance. Italian J Anim Sci 5: 43-53

Ekman P, Emanuelson H, Fransson A 1949: Investigations concerning the digestibility of protein in poultry. KGL Lantbruks - Hogskol Ann 16: 749-776

Englyst HN 1989: Classification and measurement of plant polysaccharides. Anim Feed Sci Technol 23: 27-42

Fasina YO, Classen HL, Garlich JD, Swaisgood HE, Clare DA 2003: Investigating the possibility of monitoring lectin levels in commercial soybean meals intended for poultry feeding using steam-heated soybean meal as a model. Poult Sci 82: 648-656

Ferraz de Oliveira MI, Acamovic T 1999: Apparent digestibility and endogenous amino acids in birds fed enzyme treated and untreated L. angustifolius diets. Br Poult Sci 40: 29-30

Froidmont E, Beckers Y, Dehareng F, Théwis A, Bartiaux-Thill N 2004: Lupin seed as a substitute to soybean meal in broiler chicken feeding: incorporation level and enzyme preparation effects on performances, digestibility and meat composition. 55 $5^{\text {th }}$ Annual Meeting of the EAAP, Bled, Slovenia (138), NCS5.12

Gilbert C, Acamovic T, Bedford MR 2000a: Gut morphology of chicks fed lupin-based diets with or without enzyme supplementation. Proceedings of XXI World's Poultry Congress, (CD) Montreal, Canada

Gilbert C, Särkilahti L, Apajalahti J, Acamovic T, Bedford MR 2000b: Microbial populations in caecalcontents from chicks fed lupin-based diets, with and without enzyme supplementation Proceedings of XXI World's Poultry Congress (CD), Montreal, Canada

Gracia MI, Latorre MA, Garcia M, Lazaro R, Mateos GG 2003: Heat processing of barley and enzyme supplementation of diets for broilers. Poult Sci 82: 1281-1291

Iji PA, Saki AA, Tivey DR 2001: Intestinal development and body growth of broiler chicks on diets supplemented with non-starch polysaccharides. Anim Feed Sci Technol 89: 175-188

Jamroz D 2005: Nutritional factors supporting the immune response in animals. Krmiva 47: 207-219

Józefiak D, Rutkowski A, Martin SA 2004: Carbohydrate fermentation in the avian ceca: a review. Anim Feed Sci Technol 113: 1-15

Kluge H, Hirche F, Eder K 2002: Concentrations of NSP and oligosaccharides in lupine species L. angustifolius, L. luteus and L. albus. 7. Tagung Schweine und Geflügelernaehrung, Lutherstadt Wittenberg, pp. 145-147

Kocher A, Choct M, Hughes RJ, Broz J 2000: Effect of food enzymes on utilization of lupin carbohydrates by broilers. Br Poult Sci 41: 75-82

Llames CR, Fontaine J 1994: Determination of amino acids in feeds: collaborative study. J AOAC Int 77: 13621402

Maenz DD, Irish GG, Classen HL 1999: Carbohydrate-binding and agglutinating lectins in raw and processed soybean meals. Anim Feed Sci Technol 76: 335-343

Marquardt RR, Brenes A, Zhiqun Z, Boros D 1996: Use of enzymes to improve nutrient availability in poultry feedstuffs. Anim Feed Sci Technol 60: 321-330

Martínez-Villaluenga C, Frías J, Vidal-Valverde C 2006: Functional lupin seeds (Lupinus albus L and Lupinus luteus L) after extraction of $\alpha$-galactosides. Food Chem 98: 291-299 
Mathivanan R, Selvaraj P, Nanjappan K 2006: Feeding of fermented soybean meal on broiler performance. Int J Poult Sci 5: 868-872

Mathlouthi N, Mallet S, Saulnier L, Quemener B, Larbier M 2002: Effect of xylanase and beta-glucanase addition on performance, nutrient digestibility and physico-chemical conditions in the small intestine contents and caecal microflora of broiler chickens fed a wheat and barley based diet. Anim Res 51: 395-406

Mieczkowska A, Smulikowska S, Nguyen CV 2004: Effect of enzyme supplementation of white lupin (Lupinus albus var Butan) - containing diets on performance, nutrient digestibility, viscosity, ph, and passage rate of digesta in broiler chickens. J Anim Feed Sci 13: 475-486

Naveed A, Acamovic T, Bedford MR 1998: Effect of enzyme supplementation of UK-grown Lupinus albus on growth performance in broiler chickens. Br Poult Sci 39: S36-37

Naveed A, Acamovic T, Bedford MR 1999: The influence of carbohydrase and protease supplementation on amino acid digestibility of lupin-based diets for broiler chicks. Proc Austr Poult Sci Symp 11: 93-96

Newkirk RW, Classen HL 1998: In vitro hydrolysis of phytate in canola meal with purifed and crude sources of phytase. Anim Feed Sci Technol 72: 315-327

Olkowski AA, Olkowski BI, Amarowicz R, Classen HL 2001: Adverse effects of dietary lupine in broiler chickens. Poult Sci 80: 621-625

Olkowski Bi, Classen HL, Wojnarowicz C, Olkowski AA 2005: Feeding high levels of lupine seeds to broiler chickens: Plasma micronutrient status in the context of digesta viscosity and morphometric and ultrastructural changes in the gastrointestinal tract. Poult Sci 84: 1707-1715

Orda J, Jamroz D, Wiliczkiewicz A, Wertelecki T, Skorupinska J, Broz J 2006: Effects of increased dietary inclusion of yellow lupins and enzyme supplementation on performance, ileal digestibility of nutrients and microbial status of large intestine in broiler chickens. Arch Geflügelkd 70: 14-21

Petterson DS 2000: The use of lupins in feeding systems. Review. Asian Australas J Anim Sci 13: 861-882

Rahman MH 2000: The nutritional toxicity of sweet lupin (Lupinus angustifolius) seed proteins. J Sci Food Agric 80: $72-78$

Rosin AA, Blank G, Slominski BA, Holley RA 2007: Enzyme supplements in broiler chicken diets: in vitro and in vivo effects on bacterial growth. J Sci Food Agric 87: 1009-1020

Roth-Maier D, Paulicks B 2003: Feeding and nutritional value of sweet blue and yellow lupin seed (Lupinus angustifolius L, Lupinus luteus L) for broiler chicks. Arch Geflügelkd 67: 175-178

Rubio LA, Brenes A, Centeno C 2003: Effects of feeding growing broiler chickens with practical diets containing sweet lupin (Lupinus angustifolius) seed meal. Br Poult Sci 44: 391-397

Rubio LA, Brenes A, Setien I, De La Asuncion G, Duran N, Cutuli MT 1998: Lactobacilli counts in crop, ileum and caecum of growing broiler chickens fed on practical diets containing whole or dehulled sweet lupin (Lupinus angustifolius) seed meal. Br Poult Sci 39: 354-359

Sipsas S, Glencross B 2005: Implications of variability amongst Lupin cultivars in aquaculture feeds. Processing Proceedings of the Third Workshop for Seeding a Future for Grains, (14 April 2005, Fremantle, Western Australia), pp. 7-13

Skolik J, Wiewiorowski M 1959: (In Polish) Photometric micromethod of estimation of lupin alkaloids. Rocz Chem 33: 461-469

Steenfeldt S, Gonzalez E, Knudsen KEB 2003: Effects of inclusion with blue lupins (Lupinus angustifolius) in broiler diets and enzyme supplementation on production performance, digestibility and dietary AME content. Anim Feed Sci Technol 110: 185-200

Straková E, Suchý P, Večerek V, Šerman V, Mas N, Jůzl M 2006: Nutritional composition of seeds of the genus Lupinus. Acta Vet Brno 75: 489-493

Suchy P, Straková E, Večerek V, Šerman V, Mas N 2006: Testing of two varieties of lupin seeds as substitutes for soya extracted meal in vegetable diets designed for young broilers. Acta Vet Brno 75: 495-500

Sujak A, Kotlarz A, Strobel W 2006: Compositional and nutritional evaluation of several lupin seeds. Food Chem 98: 711-719

Vasconcelos IM, Oliveira JT 2004: Antinutritional properties of plant lectins. Toxicon 44: 385-403

Wiryawan KG, Dingle JG 1999: Recent research on improving the quality of grain legumes for chicken growth. Anim Feed Sci Technol 76: 185-193

WPSA 1989: European Table of Energy Values for Poultry Feedstuff ( $3^{\text {rd }}$ ed.) Subcommittee energy of the working group no 2. Nutrition of the European Federation of branches of the World's Poultry Science Association, Spelderholt Centre for Poultry Research, Beekbergen, pp. 11-28 